\section{CarakaTanil \\ Journal of Sustainable Agriculture \\ ISSN 2613-9456 (Print) 2599-2570 (Online)}

\title{
Yields Losses Caused by Basal Plate Rot (Fusarium oxysporum f.sp. cepae) in Some Shallot Varieties
}

\author{
Hadiwiyono*, Kumala Sari and Susilo Hambeg Poromarto \\ Department of Agrotechnology, Faculty of Agriculture, Universitas Sebelas Maret, Surakarta, Indonesia \\ *Corresponding author: hadi_hpt@yahoo.com
}

\begin{abstract}
Basal plate rot or moler caused by Fusarium oxysporum f. sp. cepae (FOCe) is the most important disease of shallot. However, the information of crop losses attributed to the pathogen is still limited, especially related to resistance of shallot. This paper discusses the correlation between disease severity and resistance of some shallot varieties to yield losses. The experiment was arranged by Completely Randomized Design (CRD) with six varieties of shallot as treatments, each of which consisted of 20 shallots, with three times of replications. The independent variables were the disease severity of twisting leaf and rotting of shallot bulb. The association of disease severity versus yield losses in different varieties was based on the correlation analysis. The results showed that both variables were positively correlated to yield losses, which were significantly affected by the level of resistance. Yield losses in resistant and moderate varieties were at the ranges of 2.13-4.38 and 15, 27.26-40.04, respectively.
\end{abstract}

Keywords: disease severity; resistance; susceptible; twisting leaf

Cite this as: Hadiwiyono, Sari, K., \& Poromarto, S. H. (2020). Yields Losses Caused by Basal Plate Rot (Fusarium oxysporum f.sp. cepae) in Some Shallot Varieties. Caraka Tani: Journal of Sustainable Agriculture, 35(2), 250-257. doi: http://dx.doi.org/10.20961/carakatani.v35i2.26916

\section{INTRODUCTION}

Shallots (Allium ascalonicum L.) are an important commodities in the world and the demand of them will increase gradually, in line with the increasing population growth. Increasing shallot demand also occurred in Indonesia with the average increase of national consumption in 2014-2018, reaching 2.88\% per year (Manurung, 2019). This growing consumption is not supported by the low national productivity and often insufficient availability of commodities to meet the national demand (Yanuarti and Afsari, 2016). The presence of pests and diseases is the important constrain in shallot production. Like all other Allium crops, shallot is attacked by many diseases and insect pests at different crop growth stages and this causes considerable losses in yield (Dinakaran et al., 2013; Mishra et al., 2014).
The most noticeable disease of shallot is basal plate rot, which is popularly called moler, caused by Fusarium oxysporum f.sp. cepae (Hanzawa) Snyder \& Hansen (FOCe). Basal plate rot of shallot has the following symptoms (Armstrong and Armstrong, 1981; Michielse and Rep, 2009; Dinakaran et al., 2013). In the above ground parts, the leaves are twisting and yellowing, starting from the lower leaves. The infected plant becomes stunted. The disease can also cause delayed emergence of seedlings. In the growing stage, at the bottom of the plant, the roots and bulbs become rotted, with brown to dark brown in color. The rot often starts at the bulb base (root plate) and then it progresses upward and outward. The pathogen can also cause significant damage in the storage (Schwartz, 2008). In the fields, the disease incidents are greatly varied at the range of 13.7577.90\% (Wiyatiningsih, 2007).

\footnotetext{
* Received for publication January 11, 2019 Accepted after corrections June 12, 2020
} 
Most diseases affected by Fusarium are very difficult to control because the pathogens can survive for a long time in the soil under adverse environmental conditions, even without a host plant (Agrios, 2005; Costa et al., 2018; Arie, 2019). When the Fusarium is stressed by unfavorable environmental conditions, it will form a resistant structure called chlamydospore, which has thick walls and contains a lot of food reserves (Booth, 1971; Armstrong and Armstrong, 1981; Nelson, 1981; Costa et al., 2018; Arie, 2019)

The control of diseases attributed to Fusarium must be done through an integrated management approach (Jiménez-Díaz and Jiménez-Gasco, 2011). One important component in the management of plant diseases is planting resistant varieties (Armstrong and Armstrong, 1981; Michielse and Rep, 2009). In addition, planting resistant plants is highly relevant to the concept of sustainable agriculture, which prioritizes environmentally friendly methods, because planting resistant plants can reduce the use of pesticides, so that it can reduce the negative impacts of pesticide uses (Ronald, 2011; Velten et al., 2015; Brzozowski and Mazourek, 2018; Lampridi et al., 2019). The uses of resistant varieties are practical measures for controlling the diseases caused by Fusarium oxysporum in the field (Armstrong and Armstrong, 1981; Michielse and Rep, 2009). The studies on the resistance of some shallot varieties to basal plate rot have been conducted (Nugroho et al., 2011; Prakoso et al., 2016; Edy, 2019; Wijoyo et al., 2020) however, the information on yield losses triggered by basal plate rot is still limited. Yield loss is the quantitative decrease of the crop yield due to a single injury or an injury profile. The yield loss is the difference between the attainable yield and actual yield and it can be expressed in terms of weight or volume, or as relative yield loss $(\%)$ with respect to the attainable yield (Nutter et al., 1993; Savary et al., 2006).

In this study, the researchers define the yield loss as the difference between healthy crop yield and diseased crop yield in percentage (\%). Some scientists have reported about the effects of host varieties on basal plate rot and the yields of shallot (Prakoso et al., 2016; Edy, 2019). Prakoso et al. (2016) informed that each cultivar of shallot from several production areas in East Java had different levels of resistance. The shallot cultivar (cv.) Batuijo performed as moderately resistant, while the cultivars Bauji from Magetan and Nganjuk were susceptible to FOCe. The productivity of shallots was affected by the disease severity and the variety of shallot (Wiyatiningsih et al., 2009; Prakoso et al., 2016; Deden and Umiyati, 2017; Edy, 2019). The reports, however, did not discuss about the yield losses by the disease. The yield loss is important to describe the risk of yield reduction because of pathogen infection. The information about yield loss will be helpful in plant disease control based on disease intensity subjected to the level of plant resistance. This paper discusses the effects of the levels of disease severity and resistances of some shallot varieties inoculated with FOCe in controlled condition.

\section{MATERIALS AND METHOD}

The study was conducted in the Laboratory of Plant Pests and Diseases, Faculty of Agriculture, Universitas Sebelas Maret (UNS) Surakarta, Indonesia and greenhouse of Observation of Food Crops Pests and Diseases in Sukoharjo, belonging to the Center for Plant Protection on Food Crops, Horticultures and Plantations of Central Java in Sukoharjo (Central Java, Indonesia) in September 2017 - May 2018. The experiment applied a Completely Randomized Design (CRD). Six varieties of shallot used in this study were Bima Curut, Bima Rajat, Bauji, Tajuk, Bali Karet and Bali Lancur. Each variety was represented by 20 seeds of shallots planted in sterile planting media of soil mixed with compost with the ratio of $3: 1$ (volume) in a plastic tray $(45 \mathrm{~cm} \times 30 \mathrm{~cm} \times 20$ $\mathrm{cm})$, consisting of 3,000 $\mathrm{g}$ of air-dried soil as a treatment unit and it was repeated three times.

The inoculation was carried out by infesting and mixing the FOCe conidia suspension into the media with a density of $10^{5}$ conidia $\mathrm{g}^{-1}$ of soil. The conidia density was determined by the infestation of $300 \mathrm{ml}$ conidial suspension $\left(10^{5}\right.$ conidia $\left.\mathrm{ml}^{-1}\right)$ into the soil. In the control treatment, the seeds were planted on soil media without the infestation of FOCe. Fertilizing was done based on the recommendations from the Center for Horticultural Research and Development, Republic of Indonesia, as follows. The basic fertilizers in the forms of compost 3 ton $\mathrm{ha}^{-1}$ and dolomite $1.5 \mathrm{~kg} \mathrm{ha}^{-1}$, TSP $200 \mathrm{~kg} \mathrm{ha}^{-1}$ were applied at the age of 1 day before planting. The supplementary fertilizers I and II were given at the 
age of 15 and 30 days after planting each mixture with Urea $\left(150 \mathrm{~kg} \mathrm{ha}^{-1}\right)+\mathrm{ZA}\left(200-350 \mathrm{~kg} \mathrm{ha}^{-1}\right)+$ $\mathrm{KCl}\left(200 \mathrm{~kg} \mathrm{ha}^{-1}\right)$.

The variables observed were disease severity of twisting leaf (moler) and basal plate rot of bulb, weight of fresh plant biomass and the weight of shallot bulbs. Disease severity was accessed by the formula $D S=\frac{\sum(n x v)}{N x V} x 100 \%$ where $n$ is the observed sample, $v$ is the disease score, $N$ is the number of samples observed and $V$ is the highest disease score. The leaf twisting was scored and categorized into the followings, score $0=0 \%$ severity (no leaf twisting), score $1=1-10 \%$ leaf twisting, score $2=11-30 \%$ leaf twisting, score 3 $=31-75 \%$ leaf twisting and score $4=\geq 76 \%$ leaf twisting. The determination of basal rot disease severity was conducted based on the scoring system used by Sintayehu et al. (2011) with modification, as follows, score $0=$ no rotting, score $1=10 \%$ rotting root, score $2=10-30 \%$ rotting root with $10 \%$ rotting bulbs, score $3=$ $100 \%$ rotting root with $10-30 \%$ rotting bulbs and score $4=100 \%$ rotting root with $>30 \%$ rotting bulbs. The levels of plant resistance were determined based on the scale of diseases severity used by Esfahani et al. (2012) with a slight modification, including resistant (0-10\%), moderately resistant (11-25\%), moderate (26$50 \%)$, moderately susceptible (51-75\%) and susceptible (76-100\%).

Growth reduction in each shallot variety was decided by calculating the difference between the weight of fresh biomass of the shallots without pathogen inoculation and those of pathogen- inoculated shallots. Yield losses were associated with the difference between the weight of bulbs of shallot without inoculation and those were inoculated with the pathogen. All variables were observed at the time of harvesting or nine weeks after planting (WAP), except the growth variable that was observed at six WAP. The correlation analysis of the disease severity to growth reduction and yield losses was performed using a simple linear regression correlation. To analyze the difference between the averages Analysis of variant (ANOVA) and Duncan's Multiple Range Test (DMRT) at level of 5\% were carried out.

\section{RESULTS AND DISCUSSION}

The different shallot varieties showed various responses to FOCe infection. The responses were resistant, moderately resistant, moderate and moderately susceptible. In this study, there was no variety that showed susceptible response. The resistant response was performed by cv. Bali Lancur, moderately resistant by cv. Bali Karet, moderate by cv. Bauji and Tajuk and moderately susceptible by cv. Bima Curut and Bima Rajat. The different level of resistance gave impacts on the growth of shallots. The growth reductions of shallot depended on the responses related to the disease severity (Table 1 and Table 2). Due to the absence of variety showing susceptible, yield losses to disease severity were extrapolated by using the existed formulation of the linear correlation of disease severity to growth reductions and yield losses (Figure 2 and Figure 3).

Table 1. The responses of several shallot varieties to FOCe

\begin{tabular}{lccc}
\hline \multicolumn{1}{c}{ Variety } & Twisting leaf severity (\%) & Basal plate rot severity $(\%)$ & Response category \\
\hline Bima Curut & $57.07 \pm 15.66 \mathrm{~cd}$ & $45.50 \pm 10.94 \mathrm{c}$ & Moderately susceptible \\
Bima Rajat & $64.10 \pm 11.27 \mathrm{~d}$ & $50.67 \pm 04.44 \mathrm{c}$ & Moderately susceptible \\
Bauji & $46.17 \pm 03.33 \mathrm{~cd}$ & $30.80 \pm 00.00 \mathrm{~b}$ & Moderate \\
Tajuk & $37.17 \pm 12.51 \mathrm{bc}$ & $25.00 \pm 06.93 \mathrm{~b}$ & Moderate \\
Bali Karet & $17.97 \pm 07.28 \mathrm{ab}$ & $10.90 \pm 08.00 \mathrm{a}$ & Moderately resistant \\
Bali Lancur & $7.70 \pm 13.32 \mathrm{a}$ & $4.50 \pm 07.77 \mathrm{a}$ & Resistant \\
\hline
\end{tabular}

Note: The values in the same column followed by the same letter are not significantly different based on DMRT $(p<0.05)$

The result of regression analysis showed the coefficient of determination $\left(R^{2}\right) 0.92$ for diseases severity versus growth reduction and 0.97 for diseases severity versus yield losses. Therefore, the formulation results are significantly eligible to predict the interpolation and extrapolation value of the dependent variables. As the correlation was performed in different varieties, it is assumed that the correlation is free from other independent variables, such as the 
tolerance of the shallot varieties to fusarium infection.

The variations of disease severity among the shallot varieties were influenced by the resistance level. Saxena and Cramer (2009) stated that genetic compatibility between the host and pathogen will affect the aggressiveness of the pathogen infecting the host. According to Esfahani et al. (2012) resistance responses were determined by the genotype of each shallot variety.

The resistance of shallot varieties to basal plate rot was likely influenced by the morphological characteristics of the bulbs. Based on the visual observations, Bali Lancur shallot cultivar, which was resistant to basal plate rot, had a larger size and thicker bulb plates than the others. Shallots

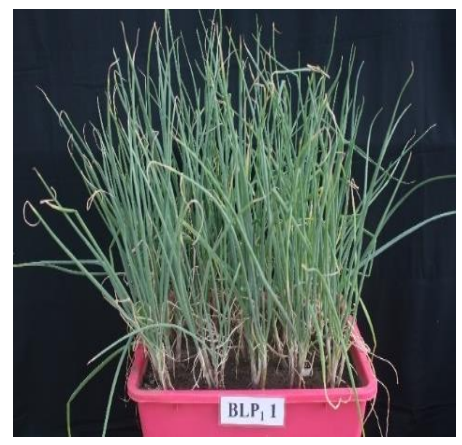

a. with thicker bulbs had a higher resistance level than those with thin bulbs. This result is also in line with a statement that thick bulb plates is more difficult for penetration and the spread of FOCe inside the host plant tissue (Prakoso et al., 2016).

The resistant and moderately susceptible responses to shallot varieties were represented by cv. Bali Lancur and Bima Rajat, respectively (Figure 1). Disease progression in Bali Lancur was much faster than in Bima Rajat. The earlier symptom of FOCe infection on Bima Rajat was shown by the twisting and yellowing of the shallot leaves, followed by wilting. This is obviously different than that was shown in Bali Lancur that remained green and vigor without clear yellowing, twisting or wilting.

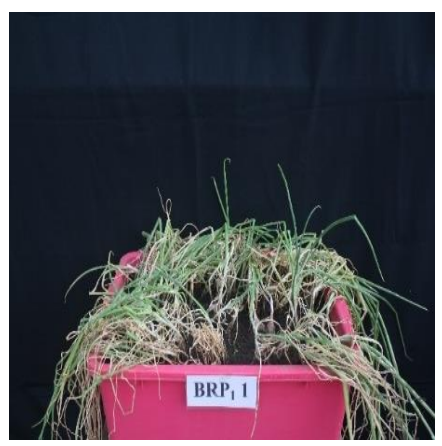

b.

Figure 1. The responses of shallots to FOCe on (a) Bali Lancur (resistant) and (b) Bima Rajat (rather susceptible)

The disease severity attributed to FOCe is influenced by the susceptibility of the host plants, virulence of pathogens and environmental conditions (Heil and Bostock, 2002). The disease intensity in Bima Rajat was more severe than in Bali Lancur. Bali Lancur was resistant to FOCe presumably because the growth of Bali Lancur variety tended to increase well until the end of the observation. Uninoculated Bali Lancur showed a better growth pattern compared to Bali Lancur. According to Agrios (2005), FOCe is difficult to infect the hosts with well growth. This is so for FOCe is a weak parasite, so that it can infect the plants that are in weak condition (Waller and Brayford, 1990; Costa et al., 2018; Rampersad, 2020).

Table 2 presents that FOCe infection had a significant effect on growth and yield of some shallot varieties. The infection on susceptible varieties causes the disturbance of physiological functions of plant, such as photosynthesis, as well as water and nutrient translocation (Agrios, 2005) and therefore, the high disease severity causes significant reduction of the growth and yield of shallots.

In terms of resistance, basal plate rot disease reduced the growth of Bali Lancur shallot by $1.88 \%$ and the crop loss was only $2.13 \%$, whereas in moderately susceptible cultivar, Bima Rajat, the disease caused growth reduction by $46.88 \%$ and crop loss of $55.97 \%$. The high growth reduction and yield losses in moderately susceptible variety were due to the high severity of the disease. Nugroho et al. (2011) specified that high intensity of basal plate rot disease can reduce the bulb weight. According to Fadhilah et al. (2014), FOCe infection inhibits shallot growth and causes yield losses as the bulbs are rotting. 
Table 2. The growth reduction and yield losses on several shallot varieties infected by FOCe

\begin{tabular}{lccc}
\hline \multicolumn{1}{c}{ Variety } & Response category & Growth reduction $(\%)^{*}$ & Yield losses $(\%)^{* *}$ \\
\hline X (predicted) & Susceptible & $\geq 49.86^{* * *}$ & $\geq 65.49^{* * *}$ \\
Bima Curut & Moderately susceptible & $30.76 \pm 21.57 \mathrm{bc}$ & $42.98 \pm 12.62 \mathrm{~cd}$ \\
Bima Rajat & Moderately susceptible & $46.88 \pm 14.99 \mathrm{c}$ & $55.97 \pm 10.71 \mathrm{~d}$ \\
Bauji & Moderate & $28.68 \pm 13.78 \mathrm{bc}$ & $40.04 \pm 05.20 \mathrm{bc}$ \\
Tajuk & Moderate & $14.07 \pm 02.73 \mathrm{ab}$ & $27.26 \pm 06.09 \mathrm{~b}$ \\
Bali Karet & Moderately resistant & $2.83 \pm 02.34 \mathrm{a}$ & $4.38 \pm 03.24 \mathrm{a}$ \\
Bali Lancur & Resistant & $1.88 \pm 00.45 \mathrm{a}$ & $2.13 \pm 02.74 \mathrm{a}$ \\
\hline
\end{tabular}

Note: $*$ = Based on the observation data on six WAP; $* *=$ Based on the observation data on nine WAP; The values in the same column followed by the same letter are not significantly different based on DMRT $(p<0.05) ; * * *=$ growth reductions and crop losses of susceptible varieties were extrapolated by linear regression analysis

In this study, there was no variety categorized as susceptible. However, the reductions of growth and the crop losses of susceptible varieties can be predicted based on extrapolation analysis using the formulation of linear regression correlation between disease severity as independent variable and growth reductions and crop losses as the dependent variables (Figure 2 and Figure 3). Extrapolation is the process of estimating variable values beyond the original observation interval gleaned from the relationship between these variables and other variables.

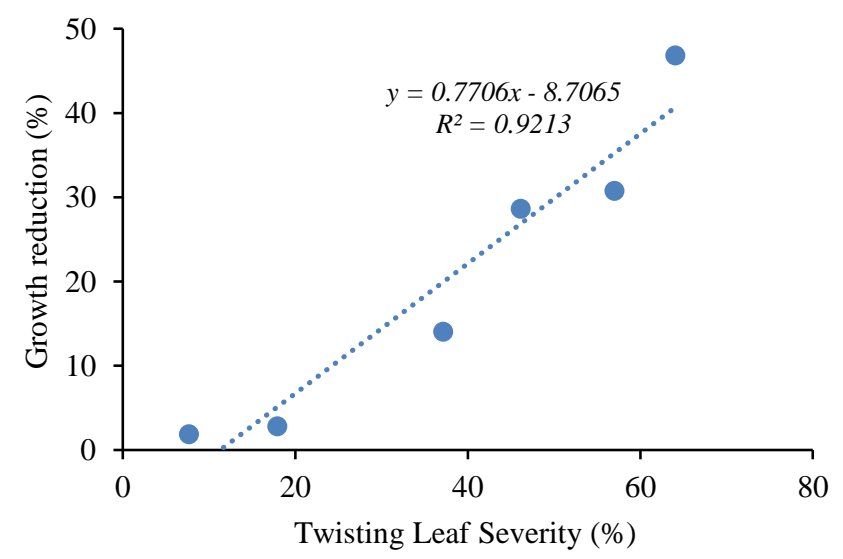

Figure 2. The linear regression correlation between twisting leaf severity and growth reductions in different shallot cultivars

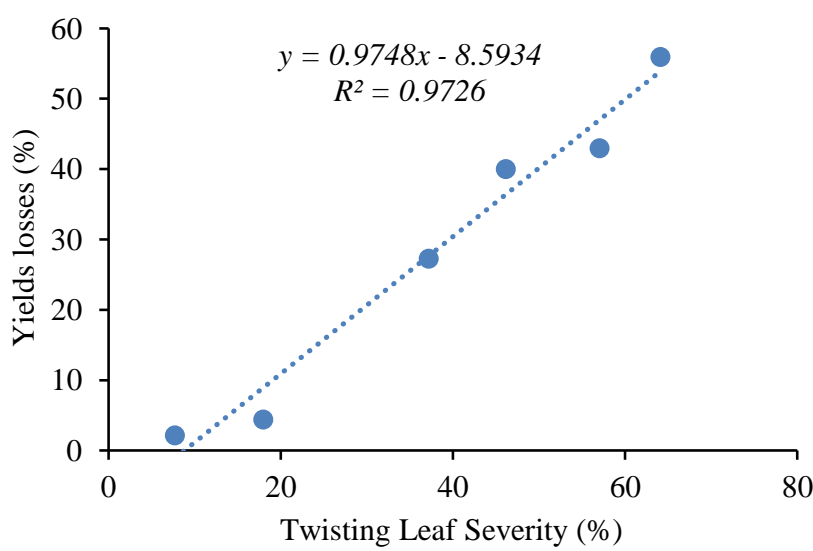

Figure 3. The linear regression correlation of twisting severity and yield losses in different shallot cultivars 
The results of the extrapolation showed that growth reduction of shallots in susceptible varieties could be $49.86 \%$ or more. Growth reduction was significantly influenced by FOCe infection. FOCe can cause physiological function of shallot to be disturbed so that the growth is not optimal. Prakoso et al. (2016) explained that after penetrating the host tissue, FOCe produces toxin, such as famoniris, which alters the elasticity of plasma membrane, so the leaves will be easily bended and twisted. According to Agrios (2005), pathogens also inhibit the process of translocation of water and plant nutrients and thus, upper parts of the infected plant cannot perform their functions properly.

Stemmed from the results of extrapolation using the function $y=0.9748 x-8.5934$, where ' $y$ ' is crop loss and ' $\mathrm{x}$ ' is twisting leaf severity, the crop losses on susceptible shallots were at $65.49 \%$ or more. Wiyatiningsih et al. (2009) recounted that FOCe infection in shallot could reduce $50 \%$ of the yields in susceptible cultivars. Whereas Sintayehu et al. (2011) reported that Fusarium basal rot caused $45 \%$ loss in yield. Similarly, in Japan, during summer period, more than $50 \%$ loss happened in welsh onion due to Fusarium basal rot (Dissanayake et al., 2009). The yield reduction could even up to $90 \%$ if the disease occurred in the seedling phase (Barnoczkine, 1986).

\section{CONCLUSIONS}

There were various responses of shallot varieties tested against FOCe infection, namely moderately susceptible (cv. Bima Rajat and Bima Curut), moderate (cv. Bauji and Tajuk), moderately resistant (Bali Karet) and resistant (cv. Bali Lancur). Growth reductions and yield losses were significantly determined by the responses of shallot varieties. Growth reduction in resistant variety (Bali Lancur) was $1.88 \%$ and yield losses in resistant-moderately resistant, moderatemoderately susceptible varieties were at the ranges of 2.13-4.38 and 27.26-55.97, respectively.

\section{REFERENCES}

Agrios, G. N. (2005). Chapter eleven - Plant diseases caused by fungi. In: Agrios, G. N. (ed). Plant Pathology (Fifth Edition), pp. 385614. https://doi.org/10.1016/B978-0-08-04737 $8-9.50017-8$
Arie, T. (2019). Fusarium diseases of cultivated plants, control, diagnosis, and molecular and genetic studies. Journal of Pesticide Science, 44(4), 275-281. http://doi.org/10.1584/jpes tics.J19-03

Armstrong, G. M., \& Armstrong, J. K. (1981). Formae speciales and races of Fusarium oxysporum causing wilt diseases. Pages 391399. In: Fusarium: Disease, Biology, and Taxonomy. P. E. Nelson, T. A. Toussoun, and $R$. J. Cook, eds. The Pennsylvania State University Press, University Park, London. Retrieved from https://scholar.google.com/ scholar_lookup?hl=en\&publication_year $=198$ 1\&pages=391-399\&author=G.+M.+Armstron g\&author $=\mathrm{J} .+\mathrm{K} .+$ Armstrong \& title $=$ Fusarium $\% 3 \mathrm{~A}+$ Disease $\% 2 \mathrm{C}+\mathrm{Biology} \% 2 \mathrm{C}+\mathrm{and}+\mathrm{Taxo}$ nomy

Barnoczkine, S. (1986). Possibilities to control Fusarium on onion. Zoldsegtermesztesi Kutato Intezet Bulletinje, 19, 33. Retrieved from https://scholar.google.com/scholar_lookup?tit le=Possibilities \%20to\%20 control\%20Fusariu m\%20on\%20onion\&author=S.\%20Barnoczki ne\&journal=Zoldsegtermesztesi $\% 20$ Kutato $\%$ 20Intezet $\% 20$ Bulletinje $\&$ volume $=19 \&$ pages $=$ 33\&publication_year=1986

Booth, C. (1971). The genus Fusarium. Kew, UK: Commonwealth Mycological Institute.

Brzozowski, L., \& Mazourek, M. (2018). A sustainable agricultural future relies on the transition to organic agroecological pest management. Sustainability, 10(6), 2023. http://doi.org/10.3390/su10062023

Costa, A. E. S., da Cunha, F. S., Honorato, A. da C., Capucho, A. S., Dias, R. de C. S., Borel, J. C., \& Ishikawa, F. H. (2018). Resistance to Fusarium Wilt in watermelon accessions inoculated by chlamydospores. Scientia Horticulturae, 228, 181-186. https://doi.org/ 10.1016/j.scienta.2017.10.007

Deden \& Umiyati, U. (2017). Pengaruh inokulasi Trichoderma sp dan varietas bawang merah terhadap penyakit moler dan hasil tanaman bawang merah (Allium ascalonicum L). Jurnal Kultivasi, 16(2), 140-148. https://doi.org/ 10.24198/kultivasi.v16i2.12213

Dinakaran, D., Gajendran, G., Mohankumar, S., Karthikeyan, G., Thiruvudainambi, S., 
Jonathan, E. I., Samiyappan, R., Pfeiffer, D. G., Rajotte, E. G., Norton, G. W., Miller, S., \& Muniappan, R. (2013). Evaluation of integrated pest and disease management module for shallots in Tamil Nadu, India: A farmer's participatory approach. Journal of Integrated Pest Management, 4(2), B1-B9. https://doi.org/10.1603/IPM12019

Dissanayake, M. L. M. C., Kashima, R., Tanaka, S., \& Ito, S. (2009). Pathogenic variation and molecular characterization of Fusarium species isolated from wilted welsh onion in Japan. Journal of General Plant Pathology, 75(1), 37-45. https://doi.org/10.1007/s10327008-0135-Z

Edy, S. (2019). Pertumbuhan dan hasil beberapa varietas bawang merah pada dua cara tanam di lahan kering dataran rendah Kota Jambi. Jurnal Agroecotenia, 2(1), 1-10. Retrieved from https://online-journal.unja.ac.id/Agroeco tania/article/view/7899

Esfahani, M. N., Hossaini, M., \& Ashrafi, N. (2012). Screening of Iranian onion seed sets genotypes for resistance to Fusarium oxysporum f.sp. cepae. Archives of Phytopathology and Plant Protection, 46(15), 1864-1873. https://doi.org/10.1080/03235408 .2013 .780371

Fadhilah, S., Wiyono, S., \& Surahman, M. (2014). Pengembangan teknik deteksi Fusarium patogen pada umbi benih bawang merah (Allium ascalonicum) di laboratorium. Jurnal Hortikultura, 24(2), 171-178. https://doi.org/ 10.21082/jhort.v24n2.2014.p171-178

Heil, M., \& Bostock, R. M. (2002). Induced systemic resistance (ISR) against pathogens in the context of induced plant defences. Annals of Botany, 89(5), 503-512. https://doi.org/ 10.1093/aob/mcf076

Jiménez-Díaz, R. M., \& Jiménez-Gasco, M. del M. (2011). Integrated management of Fusarium Wilt Diseases. In book: Control of Fusarium Diseases, Chapter: Chapter 7. Transworld Research Network \& Research Signpost, pp. 177-215. Retrieved from https:// helvia.uco.es/xmlui/handle/10396/11002

Lampridi, M. G., Sørensen, C. G., \& Bochtis, D. (2019). Agricultural sustainability: A review of concepts and methods. Sustainability,
11(18), 5120. http://doi.org/10.3390/su11185 120

Manurung, M. (2019). Konsumsi dan neraca penyediaan - penggunaan bawang merah. Buletin Konsumsi Pangan, 10(1), 55-61. Retrieved from http://epublikasi.setjen.perta nian.go.id/arsip-buletin/53-buletin-konsumsi/ 620-buletin-konsumsi-vol-10-no-1-2019

Michielse, C. B., \& Rep, M. (2009). Pathogen profile update: Fusarium oxysporum. Molecular Plant Pathology, 10(3), 311-324. http://doi.org/10.1111/j.1364-3703.2009.005 38. $\mathrm{x}$

Mishra, R. K., Jaiswal, R. K., Kumar D., Saabale, P. R., \& Singh, A. (2014). Management of major diseases and insect pests of onion and garlic: A comprehensive review. Journal of Plant Breeding and Crop Science, 6(11), 160170. https://doi.org/10.5897/JPBCS2014.0467

Nelson, P. E. (1981). Chapter 3 - Life cycle and epidemiology of Fusarium oxysporum. In Fungal Wilt Diseases of Plants (pp. 51-80). https://doi.org/10.1016/B978-0-12-464450-2. 50008-5

Nugroho, B., Astriani, D., \& Mildaryani, W. (2011). Variasi virulensi isolat Fusarium oxysporum f. sp. cepae pada beberapa varietas bawang merah. Agrin, 15(1), 8-17. Retrieved from https://jurnalagrin.net/index.php/agrin/ article/view/114

Nutter, F. W., Teng, P. S., \& Royer, M. H. (1993). Terms and concepts for yield, crop loss, and disease thresholds. Plant Disease, 77(2), 211216. Retrieved from https://lib.dr.iastate.edu/ cgi/viewcontent.cgi? article $=1064 \&$ context $=$ pl antpath_pubs\&httpsredir=1\&referer=

Prakoso, E. B, Wiyatiningsih, S., \& Nirwanto, H. (2016). Uji ketahanan berbagai kultivar bawang merah (Allium ascalonicum) terhadap infeksi penyakit moler (Fusarium oxysporum f.sp. cepae). Plumula, 5(1), 10-20. Retrieved from http://ejournal.upnjatim.ac.id/index.php/ plumula/article/view/773

Rampersad, S. (2020). Pathogenomics and management of Fusarium diseases in plants. Pathogens, 9(5), 340. https://doi.org/10.3390/ pathogens 9050340

Ronald, P. (2011). Plant genetics, sustainable 
agriculture, and global food security. Genetics, 188(1), 11-20. https://doi.org/10.1534/gene tics.111.128553

Savary, S., Teng, P. S., Willocquet, L., \& Nutter, F. (2006). Quantification and modeling of crop losses: A review of purposes. Annual Review Phytopathology, 44, 89-112. https:// doi.org/10.1146/annurev.phyto.44.070505.14 3342

Saxena, A., \& Cramer, C. S. (2009). Screening of onion seedlings for resistance against new mexico isolates of Fusarium oxysporum f. sp. cepae. Journal of Plant Pathology, 91(1), 199202. Retrieved from https://www.jstor.org/ stable/41998593?seq=1

Schwartz, H. F. (2008). Compendium of onion and garlic diseases and pests, Second Edition. Schwartz, H. F., and Mohan, S. K., eds. The American Phytopathological Society. Press, St. Paul, Minnesota, U.S.A. https://doi.org/ 10.1094/9780890545003

Sintayehu, A., Sakhuja, P. K., Fininsa, C., \& Ahmed, S. (2011). Management of Fusarium basal rot (Fusarium oxysporum f. sp. cepae) on shallot through fungicidal bulb treatment. Crop Protection, 30(5), 560-565. https:// doi.org/10.1016/j.cropro.2010.12.027

Velten, S., Leventon, L., Jager, N., \& Newig, J. (2015). What is sustainable agriculture? A systematic review. Sustainability, 7(6), 783786. http://doi.org/10.3390/su7067833

Waller, J. M., \& Brayford, D. (1990). Fusarium diseases in the tropics. Plant Pest Management, 36(3), 181-194. https://doi.org/ 10.1080/09670879009371470

Wijoyo, R. B., Sulistyaningsih, E., \& Wibowo, A. (2019). Growth, yield and resistance responses of three cultivars on true seed shallots to twisted disease with salicylic acid application. Caraka Tani: Journal of Sustainable Agriculture, 35(1), 1-11. https://doi.org/ 10.20961/carakatani.v35i1.30174

Wiyatiningsih, S., Wibowo, A., \& Triwahyu, E. P. (2009). Tanggapan tujuh kultivar bawang merah terhadap infeksi Fusarium oxysporum f. sp. cepae penyebab penyakit moler. Jurnal Pertanian Mapeta, 12(1), 1-12. Retrieved from http://eprints.upnjatim.ac.id/3146/1/Sri_ w_mapeta1101Des09.pdf

Wiyatiningsih, S. (2007). Kajian epidemi penyakit moler pada bawang merah [Dissertation] (Universitas Gadjah Mada. Yogyakarta). Retrieved from https://scholar. google.com/scholar?cluster $=14164003929662$ 341596\&hl=en\&oi=scholarr

Yanuarti, A. R., \& Afsari, M. D. (2016). Profil komoditas bawang merah. Retrieved from https://www.google.com/url?sa=t\&rct=j\&q= \&esrc $=$ s\& source $=$ web $\& c d=\& v e d=2$ ahUKEwi W252pqO7pAhXOR30KHfVtDDkQFjACeg QIAhAB\&url=https\%3A\%2F\%2Fews.kemen dag.go.id\%2Fdownload.aspx\%3Ffile\%3DBK _BAWANG_16-03-2018-SP2KP.pdf\%26type $\% 3$ Dpublication\&usg=AOvVaw3wOUfMy8I GcRG5ZGZd 